ISSN: 2302-8556

E-Jurnal Akuntansi Universitas Udayana

Vol.26.1.Januari (2019): 111-145

DOI: https://doi.org/10.24843/EJA.2019.v26.i01.p05

\title{
Opinion Shopping Sebagai Pemoderasi Pengaruh Financial Distress Pada Opini Audit Going Concern
}

\author{
Ni Putu Purnami Eka Yanti ${ }^{1}$ \\ A. A. N. B. Dwirandra ${ }^{2}$ \\ ${ }^{1,2}$ Fakultas Ekonomi dan Bisnis Universitas Udayana (Unud), Bali, Indonesia \\ e-mail: purnamiekayanti@yahoo.co.id
}

\begin{abstract}
ABSTRAK
Tujuan penelitian ini adalah untuk mengetahui kemampuan faktor kontinjensi (opinion shopping) memoderasi pengaruh financial distress pada opini audit going concern. Penelitian dilakukan pada perusahaan manufaktur yang terdaftar di Bursa Efek Indonesia tahun 2013-2017. Jumlah sampel pada penelitian ini adalah110 perusahaan. Metode pengumpulan data yang digunakan adalah metode non probability sampling dengan teknik purposive sampling. Teknik analisis data yang digunakan adalah analisis regresi logistik dan MRA.Hasil analisis menemukan bahwa financial distresstidak berpengaruh pada opini audit going concern. Perusahaan yang mengalami kesulitan keuangan belum tentu menerima opini audit going concernkarena perusahaan dapat melakukan strategic action dengan mengelola aset secara efisien. Opinion Shopping tidak mampu memoderasi financial distress pada opini audit going concern. Praktik opinion shopping ternyata tidak berpengaruh pada penerimaan opini audit non going concern.
\end{abstract}

Kata kunci: financial distress, opinion shopping, opini audit going concern.

\begin{abstract}
The purpose of this study was to determine the ability of opinion shopping to moderate the influence of financial distress on going-concern audit opinion. The study was conducted at manufacturing companies listed on the Indonesia Stock Exchange in 2013-2017. The number of samples in this study were 110 companies. The data collection method used is a non probability sampling method with a purposive sampling technique. The data analysis technique used is logistic regression analysis and MRA. The results of the analysis found that financial distress had no effect on the going-concern audit opinion. Companies that experience financial difficulties do not necessarily accept the going concern audit opinion because companies can conduct strategic actions by managing assets efficiently. Opinion Shopping is not able to moderate financial distress in going-concern audit opinion. The opinion shopping practice did not affect the acceptance of non going concern audit opinion. Keywords: financial distress, opinion shopping, going concern audit opinion.
\end{abstract}

\section{PENDAHULUAN}

Keberadaan entitas bisnis merupakan ciri dari sebuah lingkungan ekonomi yang dalam jangka panjang bertujuan untuk mempertahankan kelangsungan hidup usahanya melalui opini audit going concern. Opini yang diberikan oleh auditor merupakan informasi nyata yang terjadi pada perusahaan. Namun, pada kenyataannya banyak kasus manipulasi keuangan yang dilakukan oleh perusahaan 
Ni Putu Purnami Eka Yanti dan A.A.N.B Dwirandra. Opinion...

yang membuat investor sangat berhati- hati dalam menginvestasikan modalnya sehingga penting bagi perusahaan untuk menyediakan laporan keuangan secara wajar.

Peran auditor independen untuk memberikan opininya atas kewajaran laporan keuangan perusahaan yang terdiri neraca, laporan laba rugi, laporan laba ditahan, dan laporan arus kas.Dengan demikian, diharapkan penyedia modal dan pemegang kepentingan lainnya dapat membuat keputusan investasi, kredit, dan keputusan alokasi sumber daya lainnya yang lebih tepat berdasarkan informasi yang telah diaudit oleh pihak independen.

Paragraf 12 International Standards Auditing (ISA)seksi 570 menyebutkan bahwa auditor bertanggung jawab untuk menilai apakah terdapat kesangsian besar terhadap kemampuan perusahaan dalam mempertahankan kelangsungan usahanya (going concern) dalam periode waktu tidak lebih dari satu tahun sejak tanggal laporan audit. Asumsi going concern memiliki arti bahwa suatu badan usaha dianggap akan mampu mempertahankan kegiatan usahanya dalam jangka waktu panjang dan tidak akan dilikuidasi dalam jangka waktu yang pendek (Kim, 2016). Dalam memberikan opini going concern bukanlah perkara mudah, seringkali terjadi kesalahan opini (audit failures) oleh auditor. Penyebabnya antara lain pertama, self-fulfilling prophecy yang menyatakan bahwa ketika auditor memberikan opinigoing concern maka perusahaan akan cepat bangkrut karena terdapat konsekuensi bad news perception dari investor yang enggan menanamkan modalnya di perusahaan tersebut. Kedua, tidak 
terdapatnya prosedur penetapan status going concern yang jelas (Syahputra, 2017).

Kondisi keuangan menjadi perhatian utama auditor dalam memberikan opini going concern (Verdhyana, 2016). Ketika perusahaan mengalami masalah keuangan (financial distress), kegiatan operasionalnya pastiakan terganggu. Hal itu akan berdampak pada laba bersih negatif yang akhirnya mengalami kebangkrutan dan tidak mencukupinya arus kas operasi perusahaan untuk mencegah peristiwa tersebut (Sastrawan, 2018). Diperkuat dengan bukti empiris bahwa semakin terganggu atau memburuknya kondisi keuangan perusahaan, maka semakin besar probabilitas perusahaan menerima opini going concern (Carcello dan Neal, 2000). Sejalan dengan penelitian yang dilakukan oleh Amyulianthy (2014), Maryati (2015), Arsana (2018), Diandika (2017), Ibrahim (2014) bahwa financial distress berpengaruh positif terhadap opini audit going concern. Bertentangan dengan penelitian yang dilakukan oleh Wijayanthi (2016), Setiadamayanthi (2016), Yuliyani (2017) bahwa financial distress berpengaruh negatif terhadap opini audit going concern.

Financial distress dalam penelitian ini diukur dengan rasio leverage, yaitu debt to total asset ratio (DAR). Rasio ini dipilih digunakan untuk mengetahui kapasitas perusahaan dalam memenuhi kewajiban baik itu jangka pendek maupun jangka panjang (Benny, 2016). Diperkuat dengan penelitian sebelumnya yang dilakukan oleh Rice (2015), Triwahyuningtias (2012), Kumalaningrum (2015) dan Wijayanthi (2016) bahwa DAR berpengaruh signifikan untuk memprediksi adanya financial disress. Menurut Aryantika (2015) debt to total asset ratio yaitu 
Ni Putu Purnami Eka Yanti dan A.A.N.B Dwirandra. Opinion...

membandingkan total kewajiban dengan total aktiva. Jumlah utang yang melebihi total aktiva menyebabkan perusahaan mengalami defisiensi modal atau saldo ekuitas bernilai negatif. Semakin tinggi rasio DAR menunjukkan kinerja keuangan perusahaan yang semakin buruk dan dapat menimbulkan ketidakpastian mengenai kelangsungan hidup perusahaan. Perusahaan yang memiliki aktiva lebih kecil daripada kewajibannya akan menghadapi bahaya kebangkrutan (Chen dan Church, 1992).

Ketika perusahaan mengalami financial distress, auditor mengeluarkan opini audit going concern. Hal tersebut dapat mendorong manajemen untuk memengaruhi auditor dan menimbulkan konsekuensi negatif sehingga memungkinkan manajemen berpindah ke auditor lain untuk mengantisipasi perusahaannya menerima opini audit going concern pada tahun berjalan (Enev, 2017). Opinion shopping ini terjadi ketika tindakan perusahaan berusaha untuk memengaruhi auditor atau berpindah ke auditor lain agar bersedia mengeluarkan opini wajar tanpa pengecualian (Lopez, 2014). Manajemen akan memberikan tekanan kepada auditor dengan mengancam melakukan pergantian auditor sehingga independensi auditor terkikis. Dengan demikian, auditor bersedia untuk mengeluarkan opini wajar tanpa pengecualian.Harapan dari perusahaan adalah mendapatkan unqualified opinion setelah melakukan pergantian auditor (auditor switching).

Regulasi mengenai pergantian auditor terdapat dalam Bab V Pasal 11 Ayat (1) Peraturan Pemerintah Nomor 20 Tahun 2015 tentang pemberian jasa audit atas informasi keuangan historis sebagaimana dimaksud dalam Pasal 10 ayat (1) huruf 
a terhadap suatu entitas oleh seorang Akuntan Publik dibatasi paling lama untuk 5 (lima) tahun buku berturut- turut. Adanya kewajiban rotasi inilah yang menyebabkan perusahaan untuk melakukan auditor switching. Namun begitu, perusahaan mengganti auditor bukan karena regulasi yang berlaku, tetapi ada faktor- faktor lain yang menyebabkan perusahaan mengganti auditornya diluar regulasi yang berlaku. Faktor yang dianggap memengaruhi terjadinya pergantian auditor menurut Svanberg dan Ohman (2015) yaitu opini audit going concern dan financial distress. Diperkuat dengan penelitan sebelumnya mengenai opinion shopping antara lain Surya (2016), Hangoluan (2014), Kusumayanti (2017), Pramana (2013), Syahputra (2017), Kwarto (2015), Nanda (2015), Nursasi (2015), Iriawan (2015) yang menemukan bahwa opinion shopping berpengaruh negatif pada audit going concern. Namun, hasil penelitian dari Krissindiastuti (2016) dan Ardiani (2012) menyebutkan bahwa opinion shopping berpengaruh positif pada audit going concern.

Fenomena perusahaan yang menerima opini audit going concern pada tahun 2014 dan 2015. Dimana peneliti memilih perusahaan secara acak pada Bursa Efek Indonesia yang mengalami kerugian operasional. Tabel 1. dan Tabel 2. memperlihatkan rugi operasi yang diperoleh oleh beberapa sampel perusahaan yang terdaftar di BEI dan opini audit atas laporan keuangan perusahaan. 
Tabel 1.

Sampel Perusahaan Mengalami Rugi Operasi yang Terdaftar di BEI Tahun 2014 dan 2015

\begin{tabular}{clccc}
\hline No & \multicolumn{1}{c}{ Nama Perusahaan } & Kode & \multicolumn{2}{c}{ Laba (Rugi) } \\
& & & & \\
& & & $\mathbf{2 0 1 4}$ & $\mathbf{2 0 1 5}$ \\
\hline 1 & Bayan Resources Tbk & BYAN & Rugi & Laba \\
2 & Smartfren Telecom Tbk & FREN & Rugi & Rugi \\
3 & Bakrieland Development Tbk & ELTY & Rugi & Rugi \\
4 & Indonesia Transport dan Infrastructure Tbk & IATA & Rugi & Rugi \\
5 & Atlas Resources Tbk & ARII & Rugi & Rugi \\
6 & Alam Karya Unggul Tbk & AKKU & Rugi & none \\
7 & Arpeni Pratama Ocean Line Tbk & APOL & Rugi & Rugi \\
\hline
\end{tabular}

Tabel 2.

Sampel Perusahaan yang Terdaftar di BEI Tahun 2014 dan 2015

\begin{tabular}{clccc}
\hline No & \multicolumn{1}{c}{ Nama Perusahaan } & Kode & \multicolumn{2}{c}{ Opini Audit } \\
& & & & \\
& & & $\mathbf{2 0 1 4}$ & $\mathbf{2 0 1 5}$ \\
\hline 1 & Bayan Resources Tbk & BYAN & 1 & 0 \\
2 & Smartfren Telecom Tbk & FREN & 1 & 1 \\
3 & Bakrieland Development Tbk & ELTY & 1 & 1 \\
4 & Indonesia Transport dan Infrastructure Tbk & IATA & 0 & 0 \\
5 & Atlas Resources Tbk & ARII & 0 & 0 \\
6 & Alam Karya Unggul Tbk & AKKU & 0 & none \\
7 & Arpeni Pratama Ocean Line Tbk & APOL & 1 & 1 \\
\hline
\end{tabular}

Sumber: www.idx.co.id, 2018

Berdasarkan tabel 1 dan tabel 2 memperlihatkan bahwa terdapat ketidaksesuaian antara opini audit yang diperoleh beberapa perusahaan dengan rugi operasional. IATA, ARII, dan AKKU mengalami kerugian dari tahun 20142015 tetapi, auditor tetap memberikan opini audit non going concern yang berarti auditor tidak meragukan kelangsungan hidup perusahaan walaupun mendapat kerugian (unqualified opinion). Terdapat indikasi bahwa perusahaan- perusahaan diatas melakukan opinion shopping guna mendapat pernyataan wajar tanpa pengecualian dari auditor.

Keunikan dari penelitian ini adalah adanya variabel moderasi.Variabel yang diduga memoderasi adalah opinion shopping. Selain terdapat inkosistensi 
penelitian, tujuan dari opinion shopping sebagai variabel moderasi karena apabila perusahaan mengalami kesulitan keuangan, auditor akan menerbitkan opini audit going concern. Peneliti mengambil data dalam penelitian kurun waktu 5 (lima tahun) yaitu tahun 2013-2017.

Berdasarkan uraian latar belakang masalah tersebut, maka yang menjadi rumusan masalah dalam penelitian ini adalah apakah financial distress berpengaruh pada opini audit going concern? dan apakah opinion shopping memoderasi pengaruh financial distresspada opini audit going concern?. Tujuan penelitian ini adalah untuk mengetahui pengaruh financial distresspada opini audit going concern dan untuk mengetahui kemampuan opinion shopping memoderasi pengaruh financial distress pada opini audit going concern.

Penelitian ini memberikan kontribusi tambahan pengetahuan terkait dengan financial distress dan opinion shopping terhadap opini audit going concern pada perusahaan manufaktur.Penelitian ini dapat memberikan informasi bagi pihak manajer dalam membuat pertimbangan sehingga dapat mengambil langkah strategik dengan mengelola aset secara efisien untuk mempertahankan kelangsungan usaha perusahaan, yang akan terhindar dari kondisi financial distress.

Teori keagenan (agency theory) merupakan basis teori yang mendasari praktik bisnis perusahaan selama ini. Teori tersebut berakar dari sinergi teori ekonomi, teori keputusan, sosiologi, dan teori organisasi.Jensen dan Meckling (1976) menyatakan bahwa hubungan keagenan merupakan hubungan kontrak antara prinsipal dan agen dimana prinsipal dalam hal ini stakeholders (pemegang 
Ni Putu Purnami Eka Yanti dan A.A.N.B Dwirandra. Opinion...

saham) memberikan pertanggungjawaban atas decision making kepada agen (manajemen) sesuai dengan kontrak kerja yang telah disepakati. Hubungan antara prinsipal dan agen dapat mengarah pada kondisi ketidakseimbangan informasi (asymmetrical information) karena agen berada pada posisi yang memiliki informasi lebih banyak tentang perusahaan dibandingkan dengan prinsipal.

Kaitan teori agensi dengan penerimaan opini audit going concern, agen bertugas menjalankan perusahaan dan menghasilkan laporan keuangan sebagai bentuk dari pertanggungjawaban manajemen. Laporan keuangan ini nantinya akan menunjukkan kondisi keuangan perusahaan dan digunakan oleh prinsipal sebagai dasar pengambilan keputusan. Sebagai pihak penghasil laporan keuangan, agen memiliki keinginan untuk mengoptimalisasi kepentingannya sehingga dimungkinkan bahwa agen melakukan manipulasi data atas kondisi keuangan perusahaan. Kemungkinan terjadinya manipulasi dilakukan oleh agen, membuat diharuskan adanya pihak yang independen sebagai mediator antara agen dan prinsipal. Pihak independen ini berfungsi untuk memonitor perilaku agen apakah bertindak sesuai dengan keinginan principal (Verdhyana, 2016).Auditor merupakan pihak independen yang menjembatani hubungan antara prinsipal dan agen. Auditor mempunyai tugas untuk mengawasi kinerja manajemen apakah telah bertindak sesuai dengan kepentingan prinsipal melalui laporan keuangan (Suharsono, 2018). Auditor harus mampu bersikap independen sehingga hasil dari mengawasi kinerja manajemen menjadi obyektif dan transparan.Hasilnya berupa penerimaan opini atas kewajaran laporan keuangan yang dibuat pihak agen.Selain itu, auditor juga harus mengungkapkan kemampuan perusahaan dalam 
mempertahankan kelangsungan hidupnya (going concern). Semakin berkualitas auditor kemungkinan perusahaan untuk mendapat opini going concernakan semakin besar karena auditor akan semakin teliti memeriksa semua kejadian yang ada dalam laporan keuangan.

Teori sinyal (signalling theory) menjelaskan mengenai cara sebuah perusahaan dalam memberikan sinyal kepada pengguna laporan keuangan, yaitu berupa informasi yang diungkapkan manajemen (Butarbutar, 2011 dalamBenny, 2016). Informasi yang dipublikasikan oleh manajemen akan memberikan sinyal bagi investor dan kreditor dalam mengambil keputusan. Pada saat informasi telah diungkapkan kepada publik, pelaku pasar akan menginterpretasikan dan menganalisis informasi tersebut sebagai sebuah sinyal baik atau sinyal buruk..

Teori sinyal akan membantu perusahaan selaku agen, pemilik dan pihak luar perusahaan untuk mengurangi asimetri informasi dengan menghasilkan informasi keuangan yang disertai dengan pengungkapan berkualitas dan terintegritas (Dewi, 2018). Penerimaan opini audit going concern dianggap sebagai sinyal negatif atau buruk bagi para investor (Indriani, 2015). Opini audit going concern yang diberikan oleh pihak independen (auditor) akan memberikan persepsi negative bagi kreditor maupun investor dalam menilai kelangsungan usaha perusahaan dimasa mendatang.

MenurutSPAP (2016) opini yang diberikan merupakan pernyataan kewajaran, dalam semua hal yang material, posisi keuangan, hasil usaha, dan arus kas sesuai dengan prinsip akuntansi berterima umum. Menurut Mulyadi (2013: 20) terdapat lima jenis pendapat yang dapat diberikan oleh auditor yaitu: pendapat 
Ni Putu Purnami Eka Yanti dan A.A.N.B Dwirandra. Opinion...

wajar tanpa pengecualian (unqualified opinion), pendapat wajar tanpa pengecualian dengan bahasa penjelasan yang ditambahkan dalam laporan audit bentuk baku (unqualified opinion with modified wording or explanatory paragraph), dan pendapat wajar dengan pengecualian (qualified opinion). Pendapat tidak wajar (adverse opinion). Pernyataan tidak memberikan pendapat (disclaimer of opinion atau no opinion).

Opini audit merupakan bagian yang tidak terpisahkan dari laporan audit. Laporan audit sangat penting dalam audit atau proses atestasi lainnya karena laporan tersebut menginformasikan kepada pemakai informasi mengenaiapa yang dilakukan auditor dan kesimpulan yang diperolehnya. Going Concern adalah dalil yang menyatakan bahwa suatu entitas akan menjalankan terus operasinya dalam jangka waktu cukup lama untuk mewujudkan proyeknya, tanggung jawab, serta aktivitasnya yang tiada henti (Rahmawati, 2017).

Opini audit going concern merupakan opini audit yang dikeluarkan oleh auditor untuk mengevaluasi apakah ada kesangsian tentang kemampuan entitas untuk mempertahankan kelangsungan hidupnya (Astari, 2017). Auditor menetapkan penerimaan opini audit going concern apabila dalam proses audit ditemukan kondisi dan peristiwa yang mengarah pada kesangsian terhadap kelangsungan hidup perusahaan. Menurut ISA 570 yang termasuk dalam opini auditgoing concern terdiri dari 4 laporan, yaitu: laporan yang berisi pendapat wajar tanpa pengecualian dengan bahasa penjelas (unqualified opinion report with explanatory language), laporan yang berisi pendapat wajar dengan pengecualian (qualified opinion report), pendapat tidak wajar (adverse opinion) dan tidak 
menyatakan pendapat (disclaimer of opinion report).

Financial distress adalah sebuah kondisi dimana perusahaan sedang menghadapi masalah kesulitan keuangan. Wruck (1990) menyatakan financial distress merupakan suatu keadaan dimana arus kas operasi tidak cukup untuk memenuhi kewajiban- kewajiban lancarnya seperti utang dagang atau biaya bunga.

Opinion shopping memiliki dampak negatif, diantaranya dapat mengurangi kredibilitas laporan keuangan, kualitas keputusan investasi dan kredit yang buruk. Laporan keuangan yang dimanipulasi sering menyebabkan kehancuran bisnis sehingga berdampak pada reputasi auditor. Oleh sebab itu, dengan adanya kepentingan dalam pencapaian tujuan pelaporan perusahaan, maka manajemen cenderung mengabaikan dampak negatif tersebut (Newton, 2016). Hubungan antara opinion shopping dengan opini going concern sangat erat.

Menurut Mc Keown, et al. (1991) menyatakan bahwa auditor tidak pernah memberikan opini audit going concern pada perusahaan yang tidak mengalami financial distress. Semakin buruk kondisi keuangan perusahaan maka semakin besar probabilitas perusahaan menerima opini going concern. Sejalan dengan penelitian Ramadhany (2004) dalam Setiadamayanthi (2016) menyatakan bahwa kondisi keuangan yang dilihat dari laporan keuangan perusahaan menggambarkan kondisi kesehatan perusahaan sesungguhnya. Penelitian yang dilakukan oleh Amyulianthy (2014), Maryati (2015), Arsana (2018), Diandika (2017), Ibrahim (2014), bahwa financial distress berpengaruh terhadap opini audit going concern. 
Ni Putu Purnami Eka Yanti dan A.A.N.B Dwirandra. Opinion...

Bertentangan dengan penelitian yang dilakukan oleh Wijayanthi (2016), Setiadamayanthi (2016), Yuliyani (2017) bahwa financial distress tidak berpengaruh terhadap opini audit going concern. Opini audit going concern adalah salah satu opini yang dikeluarkan auditor jika auditor menyangsikan kelangsungan usaha suatu entitas di periode mendatang (Yudhanto dan Siti, 2012). Opini audit going concern berawal dari kondisi kesulitan keuangan perusahaan. Jika kondisi kesulitan keuangan perusahaan terjadi dalam jangka waktu yang cukup lama, maka kondisi tersebut menjadi pertimbangan auditordalam menerbitkan opini audit going concern. Berdasarkan uraian tersebut maka hipotesis dalam penelitian ini adalah sebagai berikut:

$\mathrm{H}_{1}$ : Financial distress berpengaruh positif pada opini audit going concern.

Perusahaan yang mengalami kesulitan keuangan (financial distress) dapat dilihat melalui keuangan perusahaan tersebut. Perusahaan yang memiliki jumlah kewajiban lebih besar daripada kekayaan perusahaan dapat dikatakan bahwa perusahaan sedang mengalami kesulitan keuangan (financial distress), sebaliknya apabila kewajiban perusahaan lebih kecil daripada kekayaan yang dimiliki, maka perusahaan dapat dikatakan berada dalam situasi sehat (Astrini, 2013).

Kondisi financial distress yang terjadi secara terus menerus menyebabkan kelangsungan usaha perusahaan terganggu, sehingga kemungkinan opini audit going concern akan dikeluarkan oleh auditor (Swanson, 2017). Perusahaan yang mengalami kesulitan keuangan tentu tidak menginginkan adanya opini going concern dengan dasar pemikiran bahwa manajemen mengalami kesulitan dalam menarik investor untuk menanamkan modalnya pada perusahaan. Manajemen 
cenderung memilih untuk melakukan pergantian auditor dengan harapan agar opini yang diberikan tidak terdapat paragraf modifikasi berupa going concern (Irfana, 2012). Hal ini mengakibatkan manajemen untuk melakukan aktivitas opinion shopping. Menurut Alkatiri (2016) perusahaan dikatakan berhasil dalam praktik opinion shopping ketika mendapatkan opini wajar tanpa pengecualian dari auditor baru. Hal ini dapat terjadi karena auditor mendapat tekanan dari manajemen yang menyebabkan independensi auditor menjadi terkikis (Kusumayanti, 2017). Jadi ketika pergantian auditor dilakukan, kondisi kesulitan keuangan yang dialami oleh perusahaan tidak akan berpengaruh terhadap opini going concern yang dikeluarkan oleh auditor. Berdasarkan uraian tersebut maka hipotesis dalam penelitian ini adalah sebagai berikut.

$\mathrm{H}_{2}$ : Financial distress berpengaruh negatif pada opini audit going concern ketika dilakukannya opinion shopping.

\section{METODE PENELITIAN}

Desain penelitian yang digunakan dalam penelitian ini adalah desain asosiatif. Pendekatan yang digunakan dalam penelitian ini adalah pendekatan kuantitatif dengan bentuk asosiatif.

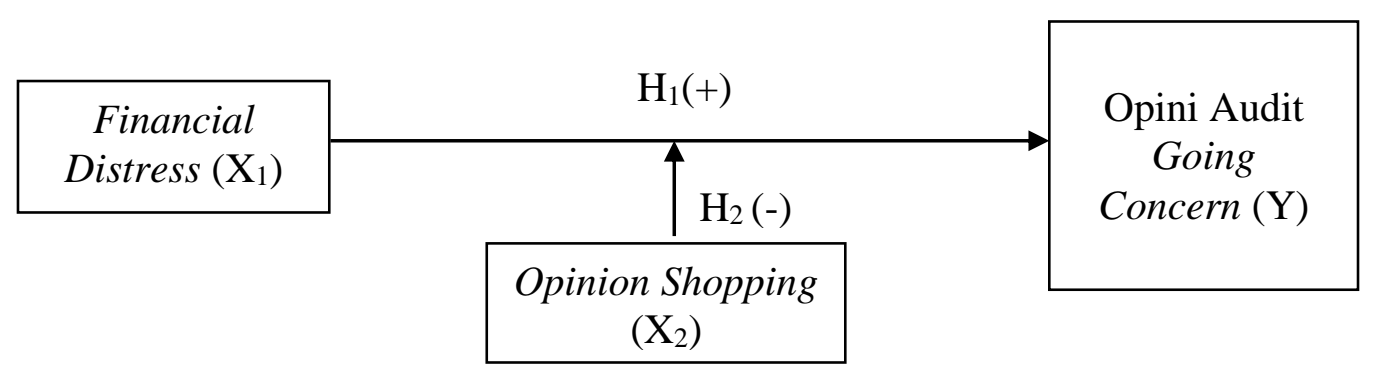

\section{Gambar 1. Desain Penelitian}

Sumber : Data diolah, 2018 
Ni Putu Purnami Eka Yanti dan A.A.N.B Dwirandra. Opinion...

Lokasi penelitian ini dilakukan pada Bursa Efek Indonesia (BEI) yang menyediakan informasi laporan keuangan perusahaan yang diaudit pada perusahaan manufaktur periode 2013-2017 melalui website resmi BEI yaitu www.idx.co.id. Lingkup dalam penelitian ini dibatasi pada pembahasan mengenai opinion shopping sebagai pemoderasipengaruh financial distress pada opini audit going concern.

Obyek penelitian yang digunakan dalam penelitian ini adalah opinion shopping sebagai pemoderasi pengaruh financial distresspada opini audit going concerndengan studi empiris pada perusahaan manufaktur yang listing di BEI tahun 2013-2017. Variabel terikat atau dependent variable adalah opini audit going concern. Variabel bebas atau independent variable adalah financial distress. Variabel moderating dalam penelitian ini adalah opinion shopping (X2).

Financial distress merupakan kondisi perusahaan yang sedang dalam keadaan kesulitan keuangan. Berdasarkan penelitian yang dilakukan oleh Triwahyuningtias (2012) mengungkapkan bahwa leverage ratio yang diukur dengan debt to total asset ratio berpengaruh positif dan signifikan dalam memprediksi kondisi financial distress. Semakin tinggi proporsi debt to total asset ratio, maka semakin besar risiko keuangan bagi kreditor maupun pemegang saham.

$$
D A R=\frac{\text { Total Utang }}{\text { Total Aset }} \times 100 \%
$$


Menurut Nanda (2015) perusahaan yang melakukan pergantian auditor setelah menerima opini audit going concern dengan maksud mendapatkan auditor yang bisa bekerja sama seusai harapan manajemen, berpotensi tinggi telah melakukan praktik opinion shopping. Sesuai ilustrasi tersebut, opinion shopping diukur menggunakan variabel dummy. Angka 1 diberikan jika perusahaan melakukan pergantian auditor ketika menerima opini audit going concern. Angka 0 jika perusahaan tidak melakukan pergantian auditor ketikamenerima opini audit going concern (Lennox, 2002).

Variabel opini audit going concern diukur menggunakan variabel dummy yang dilambangkan dengan kode 1 untuk perusahaan yang mendapatkan opini audit going concern sedangkan opini audit non going concern dilambangkan dengan kode 0 .

Populasi dari penelitian ini adalah perusahaan manufaktur yang listing di Bursa Efek Indonesia (BEI) pada tahun 2013- 2017. Jumlah dari populasi perusahaan manufaktur yang listing di BEI 2013- 2017 adalah 143 perusahaan. Menurut Sastrawan (2018) perusahaan manufaktur dipilih untuk menghindari adanya industrial effect. Industrial effect merupakan risiko industri yang berbeda antara suatu sektor industri satu dengan yang lain. Perusahaan manufaktur memiliki proporsi aktiva tetap yang lebih besar dibandingkan dengan perusahaan retail lainnya karena kegiatan usahanya membutuhkan berbagai alat produksi. Perusahaan dengan aktiva tetap lebih besar memiliki beban depresiasi yang tinggi pula, sehingga akan menimbulkan tingginya risiko usaha. Pemilihan sampel penelitian didasarkan pada metode purposive sampling digunakan karena dalam 
Ni Putu Purnami Eka Yanti dan A.A.N.B Dwirandra. Opinion...

penelitian ini ingin membahas tujuan atau topik tertentu dan kelebihan dari teknik purposive sampling ini relevan dengan tujuan penelitian. Sampel perusahaan yang digunakan dalam penelitian ini adalah 110 sampel.

Metode pengumpulan data yang digunakan yaitu metode observasi non partisipan dengan mengakses website Bursa Efek Indonesia (BEI) yaitu www.idx.co.id. Data kuantitatif dalam penelitian ini adalah laporan keuangan tahunan perusahaan manufaktur yang terdaftar di Bursa Efek Indonesia tahun 2013-2017. Data kualitatif dalam penelitian ini adalah laporan audit independen perusahaan manufaktur yang terdaftar di Bursa Efek Indonesia tahun 2013-2017. Data sekunder dalam penelitian ini adalah data laporan auditor independen dan laporan keuangan yang sudah diaudit pada perusahaan manufaktur periode 2013 sampai 2017. Data juga dapat diperoleh situs resmi IDX yaitu www.idx.co.id.

Analisis yang digunakan dalam penelitian ini adalah analisis regresi logistik yaitu dengan melihat opinion shopping sebagai pemoderasi pengaruh financial distress pada opini audit going concern. Model yang digunakan yaitu sebagai berikut:

$\operatorname{Ln} \frac{O G C}{1-0 G C}=\propto+\beta 1 F d+\beta 20 s+\beta 3 F d . O s+e$

Keterangan :

OGC : Opini Audit Going Concern ( $1=$ opini $G C$ dan $0=$ opini $n o n G C$ ).

$\beta_{1}-\beta_{5}$ : Koefisien Regresi

Fd $\quad$ :Financial Distress (rasio DAR)

Os :Opinion Shopping ( 1 = melakukan pergantian auditorketika menerima opini $G C$ dan $0=$ tidak melakukan pergantian auditor ketika menerima opini $G C$ )

e $\quad$ error 


\section{HASIL DAN PEMBAHASAN}

Proses seleksi berdasarkan kriteria yang telah ditetapkan, disajikan dalam Tabel 4.

Tabel 4.

Proses Pemilihan Sampel

\begin{tabular}{llc}
\hline No & \multicolumn{1}{c}{ Kriteria } & $\begin{array}{c}\text { Jumlah } \\
\text { Perusahaan }\end{array}$ \\
\hline 1. & $\begin{array}{l}\text { Perusahaan manufaktur yang terdaftar di Bursa Efek Indonesia } \\
\text { selama periode 2013-2017 }\end{array}$ & 143 \\
Perusahaan manufaktur yang delisting dan tidak terdaftar secara \\
berturut- turut selama periode 2013-2017 \\
$\begin{array}{l}\text { Perusahaan manufaktur yang tidak menerbitkan laporan keuangan } \\
\text { tahunan yang telah diaudit oleh auditor independen selama periode }\end{array}$
\end{tabular}

Berdasarkan data sekunder yang diperoleh dan diseleksi sesuai dengan kriteria yang sudah ditentukan, maka diperoleh sebanyak 110 sampel selama periode pengamatan tahun 2013 sampai tahun 2017. Seluruh sampel tersebut dikelompokkan menjadi dua kelompok atau kategori berdasarkan atas jenis opini audit yang diterima masing- masing perusahaan, yaitu kategori perusahaan yang menerima opini audit going concern (OGC) dan perusahaan yang tidak menerima opini audit going concern (non OGC). Distribusi perusahaan tersebut disajikan dalam Tabel 5. sebagai berikut.

Tabel 5. Distribusi Perusahaan Berdasarkan Opini Audit

\begin{tabular}{ccccccc}
\hline & \multicolumn{5}{c}{ Perusahaan } & \\
Opini & $\mathbf{2 0 1 3}$ & $\mathbf{2 0 1 4}$ & $\mathbf{2 0 1 5}$ & $\mathbf{2 0 1 6}$ & $\mathbf{2 0 1 7}$ & Total \\
\hline OGC & 6 & 7 & 9 & 8 & 6 & $\mathbf{3 6}$ \\
Non OGC & 16 & 15 & 13 & 14 & 16 & $\mathbf{7 4}$ \\
Total & $\mathbf{2 2}$ & $\mathbf{2 2}$ & $\mathbf{2 2}$ & $\mathbf{2 2}$ & $\mathbf{2 2}$ & $\mathbf{1 1 0}$ \\
\hline
\end{tabular}

Sumber: Data diolah, 2018 
Statistik deskriptif dalam penelitian ini disajikan untuk memberikan informasi tentang karakteristik variabel penelitian berupa nilai rata- rata (mean). Hasil statistik deskriptif pada penelitian ini ditunjukkan pada Tabel 6.

Tabel 6.

Statistik Deskriptif

\begin{tabular}{lrrrrr}
\hline & N & \multicolumn{1}{c}{ Minimum } & \multicolumn{1}{c}{ Maximum } & \multicolumn{1}{c}{ Mean } & Std. Deviation \\
\hline X1 & 110 & .23 & 5.07 & 1.1677 & .99347 \\
X2 & 110 & .00 & 1.00 & .1909 & .39482 \\
Y & 110 & .00 & 1.00 & .3273 & .47137 \\
X1_X2 & 110 & .00 & 2.71 & .2505 & .58782 \\
Valid N (listwise) & 110 & & & &
\end{tabular}

Berdasarkan Tabel 6. Menunjukkan $\mathrm{N}=$ nilai rata- rata (mean) dari $\mathrm{X}_{1}$ yaitu financial distress sebesar 1,1677 ini berarti bahwa 1,1677 utang dibiayai dengan 1 aset. Nilai minimum sebesar 0,23, nilai maksimum sebesar 5,07, dan standar deviasi 0,99347 . Nilai rata- rata (mean) dari $\mathrm{X}_{2}$ yaitu opinion shopping sebesar 0,1909 yang lebih kecil dari 0,50 menunjukkan bahwa opinion shopping dengan kode 1, yakni melakukan pergantian auditor ketika menerima opini audit going concern lebih sedikit muncul dari 110 perusahaan sampel. Dari 110 perusahaan sampel, 21 perusahaan sampel yang melakukan pergantian auditor ketika menerima opini audit going concern, dan 89 perusahaan sampel yang tidak melakukan pergantian auditor ketika menerima opini audit going concern.

Nilai rata- rata (mean) dari Y yaitu opini audit going concern sebesar 0,3273 yang lebih kecil dari 0,50 menunjukkan bahwa opini audit going concern dengan kode 1, yakni opini audit going concern lebih sedikit muncul dari 110 perusahaan sampel. Dari 110 perusahaan sampel, 36 perusahaan sampel yang menerima opini audit going concern, dan 74 perusahaan sampel yang tidak menerima opini audit going concern. 
Kelayakan model regresi dinilai dengan menggunakan Uji Hosmer dan Lemeshow. Hasil pengujian ditunjukkan pada Tabel 4.4.

Tabel 7.

Pengujian Hosmer dan Lemeshow's Goofness of Fit Test

\begin{tabular}{|c|c|c|c|}
\hline Step & Chi-square & df & Sig. \\
\hline 1 & 25.136 & 8 & .147 \\
\hline
\end{tabular}

Pengujian menunjukkan bahwa nilai Chi-Square sebesar 25,136dengan signifikansi 0,147. Berdasarkan hasil tersebut, nilai signifikansi lebih besar dari 0,05 sehingga dapat disimpulkan bahwa model dapat diterima karena cocok dengan data observasinya.

Menilai keseluruhan model (Overall Model Fit)dilakukan dengan membandingkan nilai antara -2Log Likelihood (2LL) pada awal (Block number= 0) dengan nilai -2 Log Likelihood (2LL) pada akhir (Block number = 1). Hasil pengujian ditunjukkan pada Tabel 8.

Tabel 8.

Perbandingan Nilai Antara -2 Log Likehood (-2LL) Awal dengan -2 Log Likehood (-2LL) Akhir

\begin{tabular}{lr}
\hline -2LL awal (Block number 0) & 139.091 \\
-2LL akhir (Block number 1) & 79.429 \\
\hline Sumber: Data diolah, 2018
\end{tabular}

Berdasarkan output tersebut, terjadi penurunan nilai antara $-2 \quad \log$ Likelihood (2LL) awal dan akhir sebesar 59,662. Penurunan nilai -2 Log Likelihood ini dapat diartikan bahwa penambahan variabel bebas ke dalam model dapat memperbaiki model fit serta menunjukkan model regresi yang lebih baik atau dengan kata lain model yang dihipotesiskan fit dengan data. 
Ni Putu Purnami Eka Yanti dan A.A.N.B Dwirandra. Opinion...

Besarnya nilai koefisien determinasi pada model regresi logistik ditunjukkan oleh nilai Nagelkerke $R$ Square. Hasil pengujian ditunjukkan pada Tabel 9.

Tabel 9.

Pengujian Koefisien Determinasi (Nagelkerke R Square)

\begin{tabular}{llll}
\hline Step & $-2 \log$ & Cox \& Snell R & Nagelkerke $R$
\end{tabular}

\begin{tabular}{lrrr}
\multicolumn{1}{c}{ likelihood } & Square & \multicolumn{2}{c}{ Square } \\
1 & $79.429^{\text {a }}$ & .419 & .583 \\
\hline Sumber: Data diolah, 2018 & &
\end{tabular}

Nilai Nagelkerke $R$ Square adalah sebesar 0,583 yang berarti variabilitas variabel dependen yang dapat dijelaskan oleh variabel independen adalah sebesar 58,3 persen, sedangkan sisanya 41,7 persen dijelaskan oleh variabel- variabel lain yang tidak disebutkan dalam model penelitin ini.

Uji multikolinearitas ini menggunakan matrik korelasi variabel bebas untuk melihat besarnya korelasi antar variabel independen.Hasil pengujian ditunjukkan pada Tabel 10.

Tabel 10.

Matriks Korelasi

\begin{tabular}{rlrrr}
\hline & & Constant & \multicolumn{1}{c}{ X1 } & \multicolumn{1}{c}{ X2 } \\
\hline \multirow{3}{*}{ Step 1 } & Constant & 1.000 & -.741 & .000 \\
& X1 & -.741 & 1.000 & .000 \\
\cline { 2 - 5 } & X2 & .000 & .000 & 1.000 \\
\hline
\end{tabular}

Hasil pengujian menunjukkan tidak ada nilai koefisien korelasi antar variabel yang nilainya lebih besar dari 0,9 maka dapat disimpulkan tidak terdapat gejala multikolinearitas yang serius antar variabel bebas.

Matriks klasifikasi menunjukkan kekuatan prediksi dari model regresi untuk memprediksi probabilitas penerimaan opini audit going concern oleh perusahaan. Hasil pengujian ditunjukkan pada Tabel 11. 
Tabel 11.

Tabel Klasifikasi

\begin{tabular}{|c|c|c|c|c|}
\hline \multirow{3}{*}{\multicolumn{2}{|c|}{ Observed }} & \multicolumn{3}{|c|}{ Predicted } \\
\hline & & \multicolumn{2}{|c|}{$\mathbf{Y}$} & \multirow{2}{*}{$\begin{array}{c}\text { Percentage } \\
\text { Correct }\end{array}$} \\
\hline & & $\begin{array}{l}\text { opini audit } \\
\text { non going } \\
\text { concern }\end{array}$ & $\begin{array}{l}\text { opini audit } \\
\text { going concern }\end{array}$ & \\
\hline \multirow{3}{*}{ Step 1} & \multirow{3}{*}{$\begin{array}{l}\text { Y opini audit non going conc } \\
\text { opini audit going concern } \\
\text { Overall Percentage }\end{array}$} & 75 & 0 & 100.0 \\
\hline & & 15 & 21 & 58.3 \\
\hline & & & & 86.4 \\
\hline
\end{tabular}

Sumber: Data diolah, 2018

Berdasarkan hasil pengujian, kekuatan prediksi dari model regresi untuk memprediksi kemungkinan perusahaan menerima opini audit going concern adalah sebesar 58,3 persen. Hal ini menunjukkan bahwa dengan menggunakan model regresi tersebut, terdapat sebanyak 21 perusahaan $(58,3$ persen $)$ yang diprediksi akan menerima opini audit going concern dari total 35 perusahaan yang menerima opini audit going concern.

Tabel 12.

Variables In The Equation

\begin{tabular}{|c|c|c|c|c|c|c|c|c|c|}
\hline & & \multirow[t]{2}{*}{$\mathbf{B}$} & \multirow[t]{2}{*}{ S.E. } & \multirow[t]{2}{*}{ Wald } & \multirow[t]{2}{*}{ df } & \multirow[t]{2}{*}{ Sig. } & \multirow[t]{2}{*}{$\operatorname{Exp}(B)$} & \multicolumn{2}{|c|}{$\begin{array}{c}\text { 95\% C.I.for } \\
\text { EXP(B) }\end{array}$} \\
\hline & & & & & & & & Lower & Upper \\
\hline \multirow{4}{*}{ Step $1^{\mathrm{a}}$} & $\mathrm{X} 1$ & .273 & .230 & 1.415 & 1 & .234 & 1.314 & .838 & 2.060 \\
\hline & $\mathrm{X} 2$ & 23.136 & 20187.095 & .000 & 1 & .999 & 11164832178.097 & .000 & . \\
\hline & $\mathrm{X} 1$ by $\mathrm{X} 2$ & -.273 & 13857.541 & .000 & 1 & 1.000 & .761 & .000 & . \\
\hline & Constant & -1.933 & .418 & 21.341 & 1 & .000 & .145 & & \\
\hline
\end{tabular}

Sumber: Data diolah, 2018

Tabel 12 menunjukkan hasil pengujian dengan regresi pada taraf kesalahan 5 persen. Hasil pengujian regresi menghasilkan sebagai berikut:

$$
\operatorname{Ln} \frac{O G C}{1-0 G C}=-1,933+0,273 F d+23,136 \text { Os }-0,273 F d . O s+e
$$

Berdasarkan model regresi yang terbentuk, dapat diinterpretasikan hasil nilai konstanta sebesar $-1,933$ menunjukkan bahwa bila tidak mengalami financial distress, tidak melakukan opinion shopping dan tidak adanya interaksi 
Ni Putu Purnami Eka Yanti dan A.A.N.B Dwirandra. Opinion...

antara financial distress dan opinion shopping, maka tidak akan menerima opini audit going concern.

Nilai koefisien regresi X1 yaitu financial distress sebesar 0,273 menunjukkan bahwa bila financial distress satu satuan, maka opini audit going concern akan mengalami peningkatan sebesar 0,273 dengan asumsi variabel lainnya konstan. Nilai koefisien regresi X2 yaitu opinion shopping sebesar 23,136 menunjukkan bahwa bila opinion shopping satu satuan, maka opini audit going concern akan mengalami peningkatan sebesar 23,136 dengan asumsi variabel lainnya konstan.

Nilai koefisien regresi X1.X2 sebesar -0,273 menunjukkan bahwa bila interaksi antara financial distress dengan opinion shopping, naik satu satuan, maka opini audit going concern akan mengalami penurunan sebesar 0,273 dengan asumsi variabel lainnya konstan.

Berdasarkan tabel variabel in the equation, diketahui bahwa opinion shopping tidak memiliki pengaruh langsung terhadap opini audit going concern dan opinion shopping tidak mampu memoderasi pengaruh financial distress pada opini audit going concern. Hal ini menunjukkan bahwa opinion shopping mampu memoderasi secara potensial (homologiser moderator).

Hipotesis pertama menyatakan financial distress berpengaruh positif dan signifikan pada opini audit going concern. Hasil pengujian dengan menggunakan rasio debt to total asset menunjukkan nilai koefisien regresi positif sebesar 0,273 dengan tingkat signifikansi 0,234 yang lebih besardari $\propto(5 \%)$. Ini menunjukkan 
$\mathrm{H}_{1}$ ditolak. Jadi dapat disimpulkan bahwa financial distress memiliki pengaruh positif namun tidak signifikan pada opini audit going concern.

Hipotesis kedua menyatakan financial distress berpengaruh negatif pada opini audit going concern ketika dilakukannya opinion shopping. Hasil pengujian interaksi financial distress dengan opinion shopping menunjukkan nilai koefisien regresi negatif sebesar 0,273 dengan tingkat signifikansi 1 yang berarti lebih besar dari $\propto(5 \%)$. Ini menunjukkan $\mathrm{H}_{2}$ ditolak.Jadi dapat disimpulkan bahwa opinion shopping tidak mampu memoderasi pengaruh financial distress pada opini audit going concern.

Variabel financial distress menunjukkan nilai koefisien regresi sebesar 0,273, dengan tingkat signifikansi 0,234 . Tingkat signifikansi menunjukkan nilai lebih besar dari 0,05 yang artinya bahwa financial distress berpengaruh positif namun tidak signifikan pada opini audit going concern. Hasil penelitian ini tidak sesuai dengan Amyulianthy (2014), Maryati (2015), Arsana (2018), Diandika (2017), Ibrahim (2014) bahwa financial distress berpengaruh positif dan signifikan terhadap opini audit going concern. Namun, penolakan ini sesuai dengan hasil penelitianSetiadamayanthi (2016) dan Verdhyana (2016). Dalam memberikan opini audit going concern, seorang auditor tentu saja sangat memperhatikan kondisi keuangan perusahaan. Perusahaan yang mempunyai permasalahan keuangan yang serius, belum tentu menerima opini audit going concern.

Hasil yang tidak signifikan pada financial distress dipengaruhi oleh range yang terlalu tinggi pada statistik deskriptif. Kondisi ini terjadi karena perusahaan 
Ni Putu Purnami Eka Yanti dan A.A.N.B Dwirandra. Opinion...

dengan tingkat kondisi keuangan yang buruk, akan tetapi memiliki perencanaan dalam memperbaiki operasi perusahaan dan kemampuan untuk mengelola keuangan dengan baik, serta mampu menyajikan laporan keuangan yang wajar, maka tidak akan menerima opini audit going concern.

Syahputra (2017) menyatakan bahwa tidak dikeluarkannya opini audit going concern pada perusahaan yang mengalami financial distress disebabkan adanya self-fulfilling prophecy bahwa ketika auditor memberikan opini going concern makaterdapat bad news perception dari investor. Hal tersebut diperkuat dengan adanya teori sinyal. Maka dari itu perusahaan memiliki upaya untuk memperbaiki permasalahan keuangannya dengan menjual seluruh aset perusahaan dikelola secara efisien dan mengalami pertumbuhan penjualan di setiap tahunnya, sehingga perusahaan memiliki dana untuk membayar kewajibannya (Fauziyah, 2015). Auditor tidak hanya mempertimbangkan rasio debt to total asset namun melihat faktor- faktor lain seperti kecukupan modal atau dampak kondisi ekonomi nasional lokasi tempat perusahaan berada. Hasil penelitian ini sejalan dengan penelitian yang dilakukan oleh Hani, dkk. (2003)dan Ibrahim (2014) membuktikan financial distress dengan rasio debt to total asset kurang dipertimbangkan oleh auditor dalam pemberian opini audit going concern.

Berdasarkan hasil pengujian financial distress yang diproksikan dengan debt to total assets menunjukkan nilai koefisien regresi sebesar -0,273 dengan tingkat signifikansi 1 . Tingkat signifikansi yang diperoleh menunjukkan nilai lebih besar dari 0,05 artinya opinion shopping tidak mampu memoderasi pengaruh financial distress pada opini audit going concern. Hasil penelitian ini tidak sesuai 
dengan Surya (2016), Kusumayanti (2017), Syahputra (2017), Kwarto (2015), yang menemukan bahwa opinion shopping berpengaruh negatif dan signifikan pada audit going concern. Perusahaan yang mengalami pergantian auditor tidak menurunkan penerimaan opini audit going concern, sebaliknya perusahaan yang tidak melakukan pergantian auditor juga tidak semakin meningkatkan penerimaan opini audit going concern. Kondisi ini terjadi ketika auditor mempunyai independensi.

Hasil penelitian ini memperkuat penelitian Kartika (2012), Pramana (2013), dan Kwarto (2015) yang menyatakan opinion shopping tidak berpengaruh pada opini audit going concern. Penelitian ini membuktikan bahwa perusahaan yang melakukan praktik opinion shopping akan tetap mendapatkan opini audit going concern. Menurut Krissindiastuti (2016) auditor yang memegang teguh pada prinsip SPAP akan mengaudit laporan keuangan perusahaan dengan baik dan benar tanpa melihat tujuan manajemen dalam praktik opinion shopping tersebut.

Walaupun perusahaan melakukan opinion shopping dengan cara melakukan pergantian auditor setelah menerima opini audit going concern, auditor yang baru tetap akan independen karena menurut Arens, et al. (2012) auditing harus dilakukan oleh orang yang kompeten dan independen, maka auditor tetap akan memberikan opini audit going concern jika terdapat kesangsian yang besar terhadap kemampuan entitas dalam mempertahankan kelangsungan hidupnya. Hasil regresi logistik menunjukkan bahwa opinion shopping tidak berpengaruh signifikan terhadap opini audit going concern. Penolakan hipotesis 
Ni Putu Purnami Eka Yanti dan A.A.N.B Dwirandra. Opinion...

ini dikarenakan opinion shopping bukan merupakan patokan dalam pemberian opini audit going concern. Sesuai dengan hasil deskriptif menyatakan bahwa, dari seluruh sampel perusahaan manufaktur di Bursa Efek Indonesia (BEI) tahun 2013-2017 terdapat 21 sampel yang diduga melakukan praktik opinion shopping, dan sebesar 89 sampel perusahaan tidak melakukan opinion shopping.

Hal ini juga sesuai dengan penelitian Ardiani (2012) dan Tarirohan (2016) yang menyatakan bahwa opinion shopping tidak berpengaruh secara signifikan terhadap penerimaan opini audit going concern. Menurut Lennox (2002), mengatakan bahwa walaupun perusahaan sering mengganti auditor setelah menerima opini audit going concern, masih belum jelas apakah ini mencerminkan praktik opinion shopping. Jadi walaupun perusahaan melakukan pergantian auditor setelah menerima atau mendapat opini audit going concern pada tahun sebelumnya, auditor yang baru tetap akan mengeluarkan opini audit going concern jika terdapat kesangsian besar terhadap kemampuan entitas dalam mempertahankan kelangsungan hidupnya.

Sejalan dengan hipotesis bahwa praktik opinion shopping dapat terjadi dalam suatu perusahaan dimana perusahaan tidak puas dengan pelayanan yang diberikan atau suatu perusahaan memiliki perselisihan dengan auditor sebelumnya. Praktik ini dapat terjadi juga untuk menghindari penerimaan opini audit going concern ketika perusahaan sedang financial distress(Teoh, 1992). Namun, menurut Arsana (2018) menyatakan bahwa pemegang saham yang menginginkan agar perusahaannya dapat berkembang akan cenderung memilih auditor yang berkualitas dan dapat memberikan opini audit dengan paragraf 
penjelas mengenai kelangsungan perusahaan yang sebenarnya.

Diperkuat oleh penelitian yang dilakukan Wijaya (2015) menyatakan bahwa perusahaan yang mengalami financial distress, cenderung untuk tidak melakukan pergantian auditor, untuk menjaga kepercayaan pemegang saham dan kreditor, jika perusahaan sering melakukan pergantian auditor, auditor baru akan tetap mencari tahu mengenai kondisi perusahaan, sehingga opini yang diperoleh dari kondisi financial perusahaan akan sama. Menurut Rahim (2016) independensi auditor mutlak harus ada pada diri auditor ketika ia menjalankan tugas pengauditan yang mengharuskan ia memberi atestasi atas kewajaran laporan keuangan kliennya. Sesuai dengan regulasi mengenai pergantian auditor terdapat dalam Bab V Pasal 11 Ayat (1) Peraturan Pemerintah Nomor 20 Tahun 2015 tentang pemberian jasa audit atas informasi keuangan historis sebagaimana dimaksud dalam Pasal 10 ayat (1) huruf a terhadap suatu entitas oleh seorang Akuntan Publik dibatasi paling lama untuk 5 (lima) tahun buku berturut- turut. Ini berarti auditor secara independen mematuhi peraturan yang telah ditetapkan oleh pemerintah.

Hasil penelitian ini juga membuktikan bahwa agency theory yaitu hubungan antara prinsipal dan agen yang mengarah pada kondisi asimetri.Dengan asimetri informasi yang dimiliki antara agen dan prinsipal, mendorong agen untuk tidak memanipulasi laporan keuangan karena memberikan sinyal negatif bagi pihak investor yang dapat menyebabkan laporan keuangan tidak reliable.

Pada penelitian ini, teori sinyal dapat mengurangi asimetri informasi dibuktikan dengan adanya opini audit going concern. Opini audit going concern 
Ni Putu Purnami Eka Yanti dan A.A.N.B Dwirandra. Opinion...

merupakan bad news bagi para investor. Ketika perusahaan menerima opini audit going concern dari auditor mencerminkan bahwa perusahaan diragukan dalam mempertahankan kelangsungan usahanya atau sedang mengalami financial distress. Namun begitu, dalam hasil penelitian ini opini audit going concern bagi pemegang saham menunjukkan bahwa auditor mempunyai kualitas yang baiksehingga hal tersebut memberikan sinyal positif bagi pihak investor bahwa perusahaan tidak melakukan manipulasi keuangan untuk menghindari adanya opini audit going concern tersebut. Penelitian ini juga membuktikan tidak semua variabel yang secara teori memengaruhi opini audit going concern.

\section{SIMPULAN}

Financial distress tidak berpengaruh pada opini audit going concern. Hasil ini menunjukkan bahwa ketika perusahaan mengalami financial distress belum tentu menerima opini audit going concern, karena perusahaan memiliki strategi untuk memperbaiki kondisi tersebut dengan mengelola aset secara efisien.

Opinion shopping tidak mampu memoderasi pengaruh financial distress pada opini audit going concern. Hasil ini menunjukkan bahwaperusahaan yang mengalami pergantian auditor tidak menurunkan penerimaan opini audit going concern, sebaliknya perusahaan yang tidak melakukan pergantian auditor juga tidak semakin meningkatkan penerimaan opini audit going concern. Kondisi terjadi ketika auditor mempunyai independensi.

Adapun saran dari penelitian bagi perusahaan adalah mampu mengindikasikan penyebab munculnya opini audit going concern. Bagi peneliti selanjutnya, dapat 
menggunakan variabel moderasi lain atau bisa dilakukan uji mediasi seperti prior opinion dan kualitas audit. Memasukkan variabel tambahan strategic action perusahaan dan rasio keuangan yang lain seperti pertumbuhan perusahaan dan profitabilitas sehingga penelitian akan lebih bisa memprediksi penerbitan opini audit going concern oleh auditor dalam jangka panjang dengan tetap memperhatikan pembedaan antara periode krisis keuangan dengan periode kondisi keuangan ekonomi normal. Pengklasifikasian mengenai opini yang masuk dalam kategori opini audit going concern sebaiknya lebih diperhatikan agar hasil penelitian selanjutnya menjadi lebih akurat.

\section{REFERENSI}

Alkatiri, Amrah Al-Khonsa, 2016. Pengaruh Opinion Shopping, Financial Distress, dan Growth Terhadap Pergantian Kantor Akuntan Publik (KAP). Jurnal Publikasi Ilmiah, 4 (5), hal. 1-30.

Amyulianthy, Rafrini. 2014. Faktor Determinan Opini Audit Going Concern. Journal Liquidity, 3(1), hal. 27-35.

Ardiani, N. Emrinaldi Nur DP.dan Nur A. 2012. Pengaruh Audit Tenure, Disclosure, Ukuran KAP, Debt Default, Opinion Shopping, dan Kondisi Keuangan Terhadap Penerimaan Opini Audit Going Concern Pada Perusahaan Manufaktur di Bursa Efek Indonesia. Jurnal Ekonomi, 20 (4), hal. 1-11.

Arens A., Randal J. Elder, Mark S, Beasley. 2012. Auditing And Assurance Services: An Integrated Approach, 14th ed. New Jersey: Prentice Hall.

Arsana, Dodi Eka. 2018. Opini Audit Going Concern Memediasi Hubungan Antara Financial Distress Terhadap Auditor Switching. E-Jurnal AkuntansiUniversitas Udayana, 24 (2), hal. 1248-1273.

Artawijaya. 2016. Pengaruh Opini Audit Going Concern dan Karakteristik Komite Audit Pada Pergantian Auditor. E-Jurnal AkuntansiUniversitas Udayana, 16 (3), hal. 1716-1743. 
Ni Putu Purnami Eka Yanti dan A.A.N.B Dwirandra. Opinion...

Aryantika, Putri. 2015. Profitabilitas, Leverage, Prior Opinion, dan Kompetensi Auditor Pada Opini Audit Going Concern. E-Jurnal AkuntansiUniversitas Udayana, 11 (2), hal. 414-425.

Astari, Wasita. 2017. Faktor- Faktor yang Mempengaruhi Penerimaan Opini Audit Going Concern. E-Jurnal AkuntansiUniversitas Udayana, 19 (3), hal. 2407-2438.

Astrini, Novia Retno. 2013. Analisis Faktor- Faktor yang Mempengaruhi Perusahaan Melakukan Auditor Switching Secara Voluntary. Journal of Accounting, 2 (3), hal. 1-11.

Benny, Priyana. 2016. Kemampuan Opini Audit Tahun Sebelumnya Memoderasi Pengaruh Profitabilitas, Leverage, Likuiditas Pada Audit Going Concern. E-Jurnal AkuntansiUniversitas Udayana, 14 (2), hal. 835-861.

Brooks, Lily Zheng. 2015. Audit Engagement Risk and the Propensity of Issuing Going- Concern-Opinion- Does Audit Firm Tenure Matter. Journal of International Business and Economics, 3 (2), hal. 17-42.

Carcello, Joseph V., and Terry L. Neal. 2000. Audit Committee Composition and Auditor Reporting.The Accounting Review, 75 (4), hal. 453-467.

Chen, Kevin C. W., and Bryan K. Church. 1992. Default on Debt Obligations and the Issuance of Opini Going- Concern Opinions. Journal of Practice \& Theory, 11(2), hal. 30-49.

Detikfinance. 2017. Rugi Bakrie Sumatera Plantation Berkurang 78\% Jadi Rp 653 Miliar. https://finance.detik.com/bursa-dan-valas/d-2876422/rugi-bakrie sumatera -plantation-berkurang-78-jadi-rp- 653-miliar.Diakses pada tanggal 5 Agustus 2018.

Detiknews. 2017. Batavia Air Pailit Karena Tak Mampu Bayar Utang US\$ 4,6 Juta. $\quad$ https://news.detik.com/berita/d-2156794/batavia-air-pailit-karenatak-mampu- bayar-utang-us-46-juta.Diakses pada tanggal 26 Maret 2018.

Dewi, Stari. 2018. Pengaruh Financial Distress dan Debt Default pada Opini Audit Going Concern. E-Jurnal Akuntansi Univeristas Udayana, 22(2), hal. 12232-1252.

Diandika, Harum. 2017. Financial Distress Sebagai Pemoderasi Pengaruh Fee Audit Pada Auditor Switching. E-Jurnal Akuntansi Universitas Udayana, 18 (1), hal. 246-275.

Enev, Maria. 2017. Going Concern Opinions and Management's Forward Looking Disclosures Evidence From the MD\&A. Journal of Accounting 
Vrije, 29 (3), hal. 1-45.

Fauziyah. 2015. Pengaruh Financial Distress terhadap Opini Audit Going Concern. Jurnal Ilmiah Cendekia Akuntansi, 3 (3), hal 1-11.

Gayoung. 2015. Managerial Overconfidence and Going Concern Modified Audit Opinion Decisions. The Journal of Applied Business Research, 31 (6), hal. 2123-2135.

Ghozali, Imam. 2016. Aplikasi Analisis Multivariate Dengan Program IBM SPSS 21. Semarang: Badan Penerbit Universitas Diponegoro.

Hani, Clearly dan Muklasin. 2003. Going Concern dan Opini Audit: Suatu Study Pada Perusahaan Perbankan di BEJ. Jurnal Akuntansi, 5 (6), hal. 12211233.

Hangoluan, Brilliant. 2014. Pengaruh Kondisi Keuangan Perusahaan, Ukuran Perusahaan, Opinion Shopping, dan Audit Client Tenure terhadap Penerimaan Opini Audit Going Concern. Jurnal Akuntansi, 4 (1), hal. 1-44.

Hartono, Jogiyanto. 2014. Metode Penelitian Bisnis. Edisi Keenam. Yogyakarta. Universitas Gadjah Mada.

Ibrahim, Safira Pramestri. 2014. Pengaruh Audit Lag, Rasio Leverage, Rasio Arus Kas, Opini Audit Tahun Sebelumnya dan Financial Distress Terhadap Penerimaan Opini Going Concern (Studi pada Perusahaan Manufaktur yang Terdaftar di BEI Tahun 2009-2012). Jurnal Akuntansi, 3 (3), hal. 2337-3806.

Indriani, Widya. 2015. Analisis Reaksi Investor Terhadap Penerimaan Laporan Opini Audit Going Concern. Journal of Accounting, 4 (2), hal. 1-8.

Institut Akuntan Indonesia. 2016. Standar Profesional Akuntan Publik. Jakarta: Salemba Empat.

Irfana, Muhammad Jauhan dan Dul Muid. 2012. Analisis Pengaruh Debt Default, Kualitas Audit, Opinion Shopping, dan Kepemilikan Perusahaan Terhadap Penerimaan Opini Audit Going Concern. Journal of Accounting, 1 (2), hal. $1-10$.

Iriawan, Wisnu Putra. 2015. Pengaruh Pertumbuhan Perusahaan, Opinion Shopping, dan Prior Opinion Terhadap Penerimaan Opini Audit Going Concern (Studi Pada Perusahaan Property and Real Estate yang Listing di BEI Tahun 2009-2013). Jurnal Akuntansi, 2 (2), hal. 1683-1690. 
Ni Putu Purnami Eka Yanti dan A.A.N.B Dwirandra. Opinion...

Jensen, M.C, and W.H. Meckling. 1976. Theory of The Firm: Managerial Behaviour Agency Cost and Ownership Structure. Journal of Financial Economics, 3 (4), hal. 305-360.

Kang, Shao, and Guang Ming. 2017. The Association Between the Internal Control and Going Concern Audit Opinions- Take the case of At Co., Ltd. Journal of Advanced Education Technology and Management Science, 6 (3), hal. 189-193.

Kartika, Andi. 2012. Pengaruh Kondisi Keuangan dan Non Keuangan Terhadap Penerimaan Opini Going Concern pada Perusahaan Manufaktur di BEI. Dinamika Akuntansi, Keuangan dan Perbankan. Jurnal Akuntansi, 1 (1), hal. 25-40.

Kim, Hak Woon. 2016. Does Revenue-Expense Matching Relate To GoingConcern Audit Opinion Conditional on Firm's Financial Distress. The Journal of Applied Business Research, 32 (3), hal. 947-966.

Krissindiastuti, Monica. 2016. Faktor- Faktor yang Mempengaruhi Opini Audit Going Concern. E-Jurnal Akuntansi Universitas Udayana, 14 (1), hal. 451481.

Kumalaningrum, Bimbi. 2015. Analisis Pengaruh Rasio Keuangan Dalam Prediksi Financial Distress Pada Perusahaan Manufaktur Yang Terdaftar di BEI Pada Tahun 2010-2013. Jurnal Akuntansi, 2 (4), hal. 1-9.

Kusumayanti, Evi. 2017. Pengaruh Opinion Shopping, Disclosure, Dan Reputasi KAP Pada Opini Audit Going Concern. E-Jurnal AkuntansiUniversitas Udayana, 18 (3), hal. 2290-2317.

Kwarto, Febrian. 2015. Pengaruh Opinion Shopping dan Pengalaman Auditor Terhadap Penerimaan Opini Audit Going Concern dalam Sisi Pandang Perusahaan Auditan. Jurnal Akuntansi, 20 (3), hal. 311-325.

Lennox, Clive S. 2002. Opinion Shopping, Audit Firm Dismissals, and Audit Committees. Journal of Accounting, 29 (1), hal. 1-34.

Lopez, Biedma. 2014. Do Independent Audit Committees Prevent Auditor Opinion Shopping? Journal of Economic, 4 (6), hal. 1-35.

Maryati, Siti. 2015. Faktor- Faktor yang Mempengaruhi Kecenderungan Penerimaan Opini Audit Going Concern pada Perusahaan Manufaktur yang Terdaftar di Bursa Efek Indonesia Periode Tahun 2010-2013. Jurnal Akuntansi, 10 (2), hal. 
Mc Keown, J.R., Jane F. Mutchler, and W. Hopwood. 1991. Toward an Explanation of Auditor Failure to Modify the Audit Reports of Bankrupt Companies. Auditing: A Journal of Practice and Theory, 32 (1), hal. 1-13.

Mulyadi, 2013.Auditing Buku 1 Edisi 6. Salemba Empat: Jakarta.

Nanda, Fini Rizki. 2015. Pengaruh Audit Tenure, Disclosure, Ukuran KAP, Debt Default, Opinion Shopping, dan Kondisi Keuangan Terhadap Penerimaan Opini Audit Going Concern. Jurnal Ekonomi dan Bisnis, 24 (1), hal. 41-60.

Nariman, Augustpaosa. 2015. Pengaruh Ukuran Kantor Akuntan Publik Terhadap Opini Going Concern dan Earnings Response Coefficients (ERC) Pada Perusahaan Manufaktur yang Terdaftar di BEI Tahun 2011-2013. Jurnal Akuntansi,19 (2), hal. 160-178.

Newton, Nathan J. 2016. Internal Control Opinion Shopping and Audit Market Competition. Journal of Accounting, 91 (2), hal. 1-30.

Nursasi, Enggar. 2015. Pengaruh Audit Tenure, Opinion Shopping, Leverage dan Pertumbuhan Perusahaan terhadap Penerimaan Opini Audit Going Concern. Jurnal JIBEKA, 9 (1), hal. 37-43.

Peraturan Pemerintah Republik Indonesia Nomor 20 Tahun 2015 tentang Praktik Akuntan Publik.

Pramana, Dedi. 2013. Analisis Faktor- Faktor yang Mempengaruhi Penerimaan Opini Audit Going Concern pada Perusahaan Manufaktur di Bursa Efek Indonesia. JurnalAkuntansi, 6 (1), hal. 1-14.

Prayanthi, Ika. 2017. The Altman Model and Auditor's Opinion About Going Concern of the Companies. Science Journal of Business and Management., 5 (5), hal. 189-193.

Rahim, Syamsuri. 2016. Pengaruh Kondisi Keuangan Perusahaan, Kualitas Audit, Opinion Shopping Terhadap Penerimaan Opini Going Concern. Jurnal Ilmiah Akuntansi dan Bisnis, 11 (2), hal. 75-83.

Rahmawati, Lina. 2017. Drivers of Going Concern Audit Opinions: Empirical Evidence from Indonesia. Journal of EconomicsIslamic, 8 (2), hal. 79-90.

Rice. 2015. Altman Z-Score: Mendeteksi Financial Distress. Jurnal Wira Ekonomi Mikroskil, 5 (2), hal. 111-120.

Safitri, Riza. 2017. Pengaruh Kondisi Keuangan Perusahaan, Ukuran Perusahaan, Opinion Shopping, Kualitas Audit, Audit Client Tenure, Debt Default, dan Audit Lag Terhadap Penerimaan Opini Audit Going Concern (Studi 
Ni Putu Purnami Eka Yanti dan A.A.N.B Dwirandra. Opinion...

Empiris Pada Perusahaan Manufaktur Yang Terdaftar di BEI Tahun 20102014). Jurnal Ekonomi, 4 (1), hal. 1374-1378.

Sari, Ni Luh Kade Merta., dan I.G.A.M. Asri Dwija Putri. 2016. Kemampuan Profitabilitas Memoderasi Pengaruh Likuiditas dan Leverage Terhadap Financial Distress. E-Jurnal Akuntansi Universitas Udayana, 5 (10), hal. 3419-3448.

Sastrawan, Ayu Ratih Kusumadewi. 2018. Anteseden Ketepatwaktuan Publikasi Laporan Keuangan Dengan Financial Distress Sebagai Pemoderasi. EJurnal AkuntansiUniversitas Udayana, 22 (2), hal. 914-943.

Setiadamayanthi, Ayu. 2016. Pengaruh Auditor Switchingdan Financial Distress Pada Opini Audit Going Concern. E-Jurnal AkuntansiUniversitas Udayana, 15 (3), hal. 1654-1681.

Sugiyono. 2017. Metodologi Penelitian Bisnis. Bandung: Penerbit Alfabeta.

Sugiyono. 2014. Metode Penelitian Kuantitatif, Kualitatif dan Kombinasi (Mixed Methods). Bandung: Alfabeta.

Suharjono, 2014.Pengaruh Opinion Shopping Terhadap Going Concern Opinion Pada Perusahaan Yang Mengalami Financial Distress.Jurnal Akuntansi, 4 (2), hal. 1-42.

Suharsono, Riyanto Setiawan. 2018. Pengaruh Kualitas Audit, Debt Default, dan Pertumbuhan Terhadap Penerimaan Opini Audit Going Concern. Jurnal Akuntansi, 2 (1), hal. 2598-2885.

Surya, Oka. 2016. Penerimaan Opini Dengan Modifikasi Going Concern dan Faktor- Faktor Prediktornya (Studi Pada Perusahaan Manufaktur di Bursa Efek Indonesia). E-Jurnal Akuntansi Universitas Udayana,14 (2), hal: 893919.

Svanberg, J. dan P. Ohman. 2015. Lost Revenues Associated with Going Concern Modified Opinions in the Swedish Audit Market. Journal of Applied Accounting Research, 15 (2), hal. 197-214.

Swanson, Zane dan Theis, John. 2017. Study of Going Concern Opinion. Journal of Accounting, Auditing, and Finance, 14 (2), hal. 1-14.

Syahputra, Fauzan. 2017. Pengaruh Audit Tenure, Audit Delay, Opini Audit Tahun Sebelumnya, Dan Opinion Shopping Terhadap Penerimaan Audit Going Concern Pada Perusahaan Manufaktur Yang Terdaftar Di Bursa Efek Indonesia Tahun 2013-2015. Jurnal Akuntansi, 2 (3), hal. 39-47. 
Tarirohan, Daulat Sahat Hatorangan dan Budiono, Eddy.2016. Pengaruh Ukuran Kantor Akuntan Publik dan Opinion Shopping Terhadap Penerimaan Opini Audit Going Concern.E- Proceeding of Management, 3 (1), hal 313-319.

Teoh, S. 1992. Auditor Independence, Dismissal Threats, and The Market Reaction to Auditor Switches. Journal of Accounting Research, 30 (1), hal. $1-23$.

Triwahyuningtias, Meilinda. 2012. Analisis Pengaruh Struktur Kepemilikan, Ukuran Dewan, Komisaris Independen, Likuiditas, dan Leverage Terhadap Terjadinya Kondisi Financial Distress. Journal of Management, 1 (1), hal. $1-14$.

Tuanakotta, Theodorus M. 2012.Audit Berbasis ISA (International Standards on Auditing). Jakarta: Salemba Empat.

Utama, Suyana. 2016. Aplikasi Analisis Kuantitatif. Edisi keenam. Denpasar: Fakultas Ekonomi Universitas Udayana.

Utami, Ayu. 2017. Kemampuan Prior Opinion Memoderasi Pengaruh Profitabilitas, Leverage, Likuiditas, Pertumbuhan Perusahaan, Dan Rasio Aktivitas Terhadap Opini Audit Going Concern. E-Jurnal Akuntansi Universitas Udayana, 6 (7), hal. 2861-2888.

Verdhyana, Okta. 2016. Auditor Switching Sebagai Pemoderasi Pengaruh Kondisi Keuangan Pada Opini Audit (Going Concern). E-Jurnal AkuntansiUniversitas Udayana, 16 (1), hal. 214-243.

Wijaya, Edwin. 2015. Pengaruh Audit Fee, Opini Going Concern, Financial Distress, Ukuran Perusahaan, Ukuran KAP Pada Pergantian Auditor. EJurnal Akuntansi Universitas Udayana, 11 (3), hal. 940-966.

Wijayanthi, Krisna. 2016. Financial Distress Sebagai Pemoderasi Pengaruh Opini Audit Going Concern Pada Ketepatwaktuan Publikasi Laporan Keuangan. E-Jurnal Akuntansi Universitas Udayana, 17 (2), hal. 1283-1310.

Wruck, K. 1990. Financial Distress, Reorganization, and Organizational Efficiency. Journal of Financial Economics, 27 (2), hal. 419-444.

Yudhanto, Adi Anggoro dan Siti Mutmainah. 2012. Faktor- Faktor Non Keuangan yang Mempengaruhi Dikeluarkannya Opini Audit Going Concern. Jurnal Akuntansi, 1 (2), hal.1-14.

Yuliyani, Ade. 2017. Pengaruh Financial Distress, Profitabilitas, Leverage, dan Likuiditas Pada Opini Audit Going Concern. E-Jurnal Akuntansi Universitas Udayana, 19 (2), hal. 1490-1520. 